\title{
Laetiporus sulphureus (Bull.: Fr.) Murr. as Food as Medicine
}

\author{
Somanjana Khatua, Sandipta Ghosh, Krishnendu Acharya*
}

\section{Somanjana Khatua, Sandipta Ghosh, Krishnendu Acharya*}

Molecular and Applied Mycology and Plant Pathology Laboratory, Department of Botany, University of Calcutta, 35, Ballygunge Circular Road, Kolkata, 700019, West Bengal, INDIA.

\section{Correspondence}

\section{Krishnendu Acharya}

Molecular and Applied Mycology and Plant Pathology Laboratory, Department of Botany, University of Calcutta, 35, Ballygunge Circular Road, Kolkata, 700019, West Bengal, INDIA.

E-mail: krish_paper@yahoo.com

\section{History}

- Submission Date: 25-08-2017;

- Review completed: 11-09-2017;

- Accepted Date: 02-11-2017

\section{DOI : 10.5530/pj.2017.6s.151}

Article Available online

http://www.phcogj.com/v9/i6s

\section{Copyright}

(C) 2017 Phcog.Net. This is an openaccess article distributed under the terms of the Creative Commons Attribution 4.0 International license.

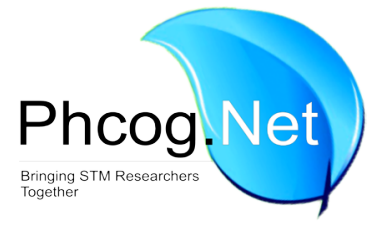

\begin{abstract}
Laetiporus sulphureus is a sulphur yellow coloured polyporous mushroom and popularly known as "chicken of the woods". Over the generations, this cosmopolitan macrofungus has become an integral part of tribal cuisines particularly for its taste. Besides, it has equal importance in folk medicine being widely used for treatment of pyretic diseases, coughs, gastric cancer and rheumatism. Thus, the species is considered as a natural reservoir of both nourishment as well as drug therapy and consequently it has become increasingly popular in scientific world. Nutritional sciences recently have witnessed it as a sustainable food supply to growing population due to enrichment of carbohydrate (trehalose> mannitol> fructose), protein (histidine, isoleucine, leucine, lysine, methionine, threonine), minerals (calcium, phosphorus, magnesium, sodium, potassium, iron, zinc, manganese, copper), vitamins (B, D, E), polyunsaturated fatty acids (linoleic acid, oleic acid, palmitic acid) and fibre. Conversely, the mushroom has also been regarded as an abundant source of chemical compounds including phenolics, triterpenes, polysaccharides with wide range of biological activities such as antiinflammatory, antimicrobial, antioxidant, antihyperglycemic, antitumor and immunomodulation effects. Therefore, a complete summary of the research progress on this fungus is necessary for further studies and commercial exploitation. In this context, the present review attempts to congregate current knowledge on nutritional value, myco-chemistry and therapeutic potential of this culturally important species. However, investigation on bioavailability, quality control, toxicology data and clinical assessment are highly recommended for future research. Key words: "Chicken of the Woods," Ethnic Relevance, Nutritious Food, Bioactive Components, Pharmacological Effects, Commercial Importance.
\end{abstract}

\section{INTRODUCTION}

Laetiporus sulphureus was originally described as Boletus sulphureus in 1789 by French mycologist, Jean Baptiste Francois (Pierre) Bulliard. In 1904, the genus was first created by famous American mycologist, William Alphonso Murill, and typified by B. sulphureus. Later in 1920, he moved Polyporus sulphureus (Bulliard) Fries to the genus and sanctioned the macrofungus with its correct name. ${ }^{1,2}$ According to scientific classification, the taxon belongs to division Basidiomycotina, subdivision Agaricomycotina, class Agaricomycetes, order Aphyllophorales and family Polyporaceae. The mushroom is distributed worldwide especially in Europe, Asia and North America from tropical to subtropical zones. It is frequently found during May to October grown solitary or in large clusters of 5-50 in a semi-circular form on stems of many living deciduous and coniferous trees, as well as on dead logs. The fungus arises mostly with Quercus, however it also occurs on living Larix decidua or Acacia sp. in subalpine zone and on broadleaf trees in montane regions. ${ }^{1-3-7}$ The mushroom is easily recognizable in forests and urban areas due to its impressive size (up to $40 \mathrm{~cm}$ wide) and vibrant bright sulphur yellow to orange coloured porous basidiocarps. ${ }^{8}$ This remarkable pigmentation accounts for its specific epithet (Laetiporus means with bright pores and sulphureus means colour of sulphur) and trivial name under which this fungus is known i.e. sulphur polypore and sulphur shelf. However, the species is also distinguishable by its extremely large bracket like fruit bodies with wet biomass over $40 \mathrm{~kg}$, fleshy margin and tubular hymenopores. ${ }^{2,3,9}$ Figure $1 \mathrm{~A}$ and $1 \mathrm{~B}$ represent photograph of the fruiting bodies naturally grown under Bambusa vulgaris in a coastal area of West Bengal, India.

Apart from appearance the flavour, texture and odour of L. sulphureus are also remarkably distinguishable. The aroma has been found to be more or less pleasant to strongly fungoid, while taste has been described as meat of chicken, crab or lobster. ${ }^{10}$ Thus the mushroom is often called as "crab of the woods", "chicken of the woods", "chicken polypore" or "chicken mushroom" and can be considered as an alternate for chicken in vegetarian diet. ${ }^{5}$ This unique fragrance and texture have influenced the use of young fruit bodies as a valuable food source for many years in oriental cultures. Unlike other polypores, the mushroom has a long history of consumption especially in North America, Japan and Thailand where it is considered a 


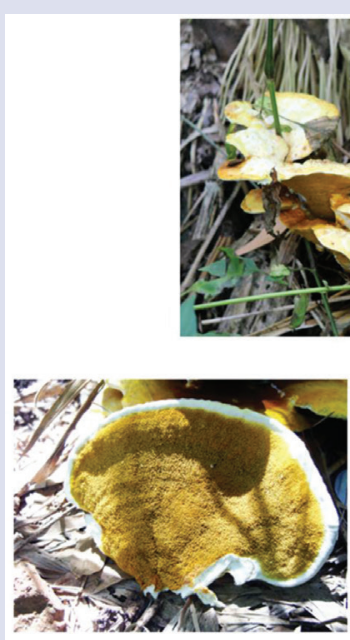

B

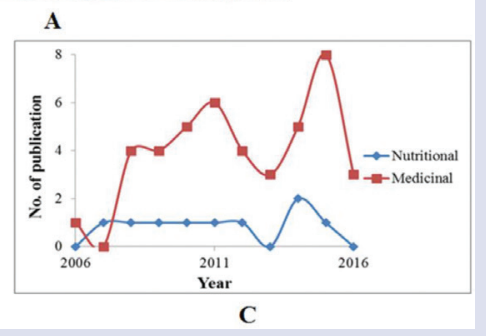

Figure 1: A: Photograph of fruiting bodies of Laetiporus sulphureus naturally grown under Bambusa vulgaris in a coastal area of West Bengal, India B: Porous fruiting body C: Number of publications reporting nutritional value and medicinal activities of Laetiporus sulphureus from the year 2006 to 2016

delicacy. ${ }^{11}$ During past decades, this ethno-mycological aspect has been dealt with many scientists in different parts of the world (Figure 1C). Analysis of multiple studies have shown that nutritionally the mushroom provides various key components such as carbohydrate, proteins including essential amino acids, vitamins, minerals, essential fatty acids and fibre which may offer excellent opportunity to promote public health. Moreover, L. sulphureus is also being appreciated as a folk remedy especially in Asia and Europe for its therapeutic attributes. ${ }^{12}$ Traditional use of the fruit bodies for treatment of pyretic diseases, coughs, gastric cancer and rheumatism is being widely followed in European countries. ${ }^{11}$ However, the mushroom became highlighted in scientific world during 1960s after successful biosynthesis of eburicoic acid. ${ }^{1}$ Later on, several biologically active components and extracts have been prepared from fruiting bodies or mycelia exhibiting a number of medicinal properties such as immunomodulation, antitumor, hem agglutination, anticoagulation, antioxidant, antibacterial, antifungal, insecticidal, anti-ulcer, insulin tropic, anti-HIV and cytostatic activities. ${ }^{9,13}$ In a recent work, the mushroom has been cultivated on a larger scale in laboratory both as fruiting bodies and hyphal mycelium which may open way to commercial production. ${ }^{2}$ Thus, the mushroom is regarded as a promising candidate for biotechnology studies reflected by huge number of publication from different countries of world (Figure 2). Recently, an excellent review on bioactive components and medicinal attributes on this mushroom has been published by Radic et al. (2009). ${ }^{1}$ However, the information should be updated by incorporating recent outcomes and a compiled study is necessary to get an updated summary. In that view, article written by Grienke et al. (2014) $)^{11}$ is highly suitable, although the overview was confined to European polypores. Therefore, this review intends to provide a comprehensive worldwide information on the fungus as a valuable health promoting medicinal food so that researchers and food industrialists can acquire current scientific knowledge.

\section{NUTRITIONAL VALUE}

During 1940s, the nutritional value of mushrooms became highlighted under impact of war time food shortages. Since then, scientists are investigating on dietary constituents of edible macrofungi in search of alter-

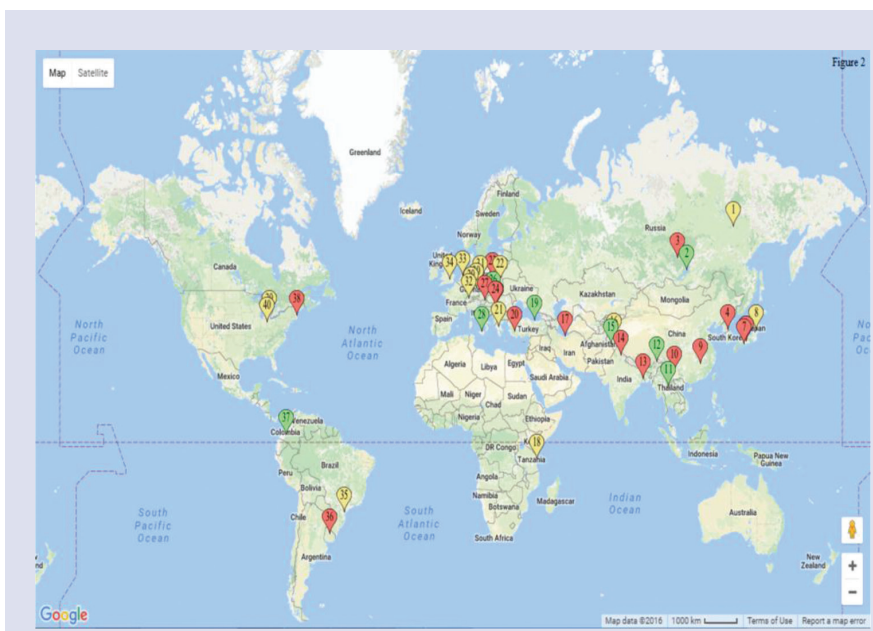

Figure 2: An overview of places in world where wild specimens of Laetiporus sulphureus have been used for research. The map has been generated automatically with help of www.mapcustomizer.com where yellow, green and red colours designate report of bioavailability, nutritional value and medicinal attributes of the fungus. Name of the places are as follows: 1. Jakutsk, Siberia, Russia 2. Lake Baikal, Russia 3. Slyudyansk and Irkutsk regions, Russia 4. Mt. Odae, Gangwon Province, Korea 5. Ashiu Experimental Forest of Kyoto University, Japan 6. Ashibidani, Shiga prefecture, Japan 7. Tokushima prefecture, Japan 8. Mt. Gassan, Yamagata Prefecture, Japan 9. FenYi, JiangXi Province, China 10. Ailao Mountain, Yunnan province, China 11. Chiang Rai, Thailand 12. Arunachal Pradesh, India 13. Coastal area of West Bengal, India 14. Dehradun, India 15. Rawalakot and Dhirkot, Azad Jammu and Kashmir 16. Gilgit-Baltistan, Pakistan 17. Mazandaran, Iran 18. Oyster Bay and Mtoni mangrove forests along Indian Ocean in Dar es Salaam, Tanzania 19. Giresun-Bulancak, Black Sea Region, Turkey 20. Denizli, Turkey 21. Greece 22. Lublin, Poland 23. South Poland 24. Belgrade, Serbia 25. Jojkićev branch of Danube River, near Pančevo, Northern Serbia 26. Hungarian Middle-Mountain 27. Slovenska Bistrica, Slovenia 28. Sicily, Italy 29. Tübingen, Germany 30. Happerg, Germany 31. Saxony, Germany 32. Switzerland 33. Baarn, Netherlands 34. Royal Holloway College, United Kingdom 35. Curitiba, State of Parana, Brazil 36. Uruguay 37. Andina region, Colombia 38. MIT, USA 39. Ann Arbor, MI, USA 40. North-eastern Ohio

native food source especially in case of protein deficiency. Generally, fruiting bodies of mushroom contain about 56.8\% carbohydrate, $25 \%$ protein, $12.5 \%$ ash, $11 \%$ fibre and $5.7 \%$ fat on dry weight (DW) basis. ${ }^{14}$ According to recommended daily allowances (RDA), on an average $300 \mathrm{~g}$ carbohydrate, $50 \mathrm{~g}$ protein, $65 \mathrm{~g}$ total fat and $25 \mathrm{~g}$ dietary fibre are sufficient to meet nutrient requirements of nearly all healthy people. Thus, it has been estimated that usually the content of carbohydrate, protein and fibre of mushrooms range from $51-88 \%, 19-35 \%$ and $4-20 \%$ of RDA respectively. ${ }^{15}$ Consequently, L. sulphureus has also appeared as an excellent nutrient supply that influenced extensive studies in different laboratories. However, data varies considerably as a number of factors influence the nutritional value such as growing site, nature of substrate, pileus size, developmental stages and part of fungal samples analysed. ${ }^{16}$

\section{Moisture}

Moisture content is important to be considered before consumption as it affects food quality. Water quantity provides a medium to support microbial growth, thus it is directly related with freshness and stability of nutrients for long term storage. However, lower moisture content leads to harder texture that typically have longer shelf life. ${ }^{17}$ Researchers 
have demonstrated that overall mushrooms contain $80-90 \%$ water and $10-20 \%$ dry matter. ${ }^{14,18}$ However, the water content in L. sulphureus has been reported to be lesser in quantity as it ranges from $72.69 \%$ to $66.67 \%$ (Table 1).

\section{Carbohydrate}

Carbohydrates are the main source of energy of body and should be the major part of total daily intake as they are more easily digested. According to published data, carbohydrate content of mushroom represents the bulk of fruiting bodies accounting for 50 to $65 \%$ on DW basis. ${ }^{18}$ Consequently, carbohydrate has been also found to be the most abundant macronutrient in L. sulphureus. Till now, seven groups of researchers have reported the carbohydrate content which ranged from 64.9 to $74.47 \mathrm{~g} / 100 \mathrm{~g}$ DW (Table 1). ${ }^{3,4,19}$ Furthermore, composition of free sugars has also been reported as determined by high performance liquid chromatography (HPLC). Chromatogram identified trehalose as the dominant sugar ( $4 \mathrm{~g} / 100 \mathrm{~g} \mathrm{DW})$, closely followed by mannitol $(3.54 \mathrm{~g} / 100 \mathrm{~g} \mathrm{DW})$, while fructose was present in minor amount $(0.46 \mathrm{~g} / 100 \mathrm{~g} \mathrm{DW}){ }^{4}$

\section{Protein}

Protein plays a major role in the body from building tissues to making hormones. The basic function of protein is to supply adequate amounts of amino acids to body. ${ }^{20}$ In this context, mushrooms are highly suitable candidate as their protein content ranges between $0.8-3.5 \mathrm{~g} / 100 \mathrm{~g}$ fresh matter and between 19-39 g/100 g dry matter. ${ }^{16}$ The informative data on crude protein content of $L$. sulphureus is highly comparable although values vary considerably (10.61-21 g/100 g DW) (Table 1). Furthermore, protein quality of the mushroom became more highlighted after exploration of its free amino acid composition as determined by Agafonova et al. (2007) using cultures of two strains LS-BG-0804 and LS-UK-0704. Remarkably, among nine essential amino acids total six have been reported from both strains (histidine, isoleucine, leucine, lysine, methionine and threonine) while leucine and histidine were dominant in LS-BG-0804 and LS-UK-0704 respectively. ${ }^{21}$

Fat

In mushrooms, the fat content is very low (about $2-8 \%$ of DW basis) where they are dominated by unsaturated fatty acids. ${ }^{18}$ Several researches have published fat content in L. sulphureus from different parts of the world that ranged from 1.23 to $2.96 \mathrm{~g} / 100 \mathrm{~g}$ DW (Table 1). Moreover, Petrović et al. (2014) have determined fatty acid composition and they reported linoleic acid (63.27\%) as the most abundant fatty acid, followed by oleic acid (14.52\%) and palmitic acid (11.68\%). The composition resulted in enrichment of PUFAs (64.14\%) while saturated and monounsaturated fatty acids were present in lower amounts $(20.54 \%$ and $15.32 \%$, respectively). ${ }^{4}$ Likewise, the lipid composition of two strains

Table 1: Macronutrients and energy content of Laetiporus sulphureus collected from different places of world.

\begin{tabular}{|c|c|c|c|}
\hline Macro-constituents & Place of collection/Type of culture strain & Quantity & Reference \\
\hline \multirow[t]{2}{*}{ Moisture (\%) } & Sicily (southern Italy) & 72.69 & [22] \\
\hline & Arunachal Pradesh & 66.67 & [28] \\
\hline \multirow[t]{4}{*}{ Carbohydrate (g/100 g DW) } & Hungarian Middle-Mountain & 74.47 & [3] \\
\hline & Northern Serbia & 72.64 & {$[4]$} \\
\hline & Strain MFLUCC 12-0546 & 71.74 & {$[2]$} \\
\hline & Black Sea Region (Turkey) & 64.9 & [19] \\
\hline \multirow[t]{5}{*}{ Protein (g/100 g DW) } & Arunachal Pradesh & 21 & [28] \\
\hline & Northern Serbia & 15.97 & [4] \\
\hline & Azad Jammu and Kashmir, Pakistan & 15.68 & [7] \\
\hline & Black Sea Region (Turkey) & 11.9 & [19] \\
\hline & Hungarian Middle-Mountain & 10.61 & [3] \\
\hline \multirow[t]{5}{*}{ Fat (g/100 g DW) } & Hungarian Middle-Mountain & 2.96 & [3] \\
\hline & Arunachal Pradesh & 2.45 & [28] \\
\hline & Northern Serbia & 2.35 & {$[4]$} \\
\hline & Strain MFLUCC 12-0546 & 1.7 & [2] \\
\hline & Sicily (southern Italy) & 1.23 & [22] \\
\hline \multirow[t]{4}{*}{ Ash (g/100 g DW) } & Northern Serbia & 9.03 & [4] \\
\hline & Hungarian Middle-Mountain & 6.39 & [3] \\
\hline & Black Sea Region (Turkey) & 4 & [19] \\
\hline & Azad Jammu and Kashmir, Pakistan & 3.956 & [7] \\
\hline \multirow[t]{4}{*}{ Fibre $(\mathrm{g} / 100 \mathrm{~g}$ DW) } & Azad Jammu and Kashmir, Pakistan & 7.157 & [7] \\
\hline & Strain MFLUCC 12-0546 & 6.43 & [2] \\
\hline & Hungarian Middle-Mountain & 5.55 & [3] \\
\hline & Arunachal Pradesh & 4.12 & [28] \\
\hline \multirow[t]{3}{*}{ Energy (kcal/100 g DW) } & Northern Serbia & 375.62 & {$[4]$} \\
\hline & Hungarian Middle-Mountain & 341.06 & [3] \\
\hline & Black Sea Region (Turkey) & 360 & [19] \\
\hline
\end{tabular}


namely LS-UK-0704 and LS-BG-0804 typically had unsaturated fatty acid in higher amounts (saturated: unsaturated fatty acid=1:2.29) where linoleic acid was dominant ( 47.50 and $48.19 \%$ respectively) followed by oleic acid (19.33 and $19.43 \%$ respectively). ${ }^{21}$ However, the reported value differed from qualitative composition of fatty acids published by Palazzolo et al. (2012). ${ }^{22}$ According to them, the dominant fatty acid was oleic acid followed by linoleic acid. Additionally, the fungus was also analysed to determine composition of sterol, another class of nutrients made up of dietary fats and investigation identified cerevisterol and ergosterol peroxide ( $5 \alpha, 8 \alpha$-epidioxy- $22 E$-ergosta-6,22-dien-3 $\beta$-ol) ${ }^{23}$

\section{Energy}

Energy content of a diet is derived by calculation from energy yielding constitutes using 17, 37 and $17 \mathrm{~kJ} / \mathrm{g}$ conversion factors for total carbohydrates, fat and protein respectively. In case of female and male adults in sedentary lifestyle the recommended energy values are about 2910 $\mathrm{kJ} /$ serving and $3060 \mathrm{~kJ} /$ serving respectively. ${ }^{24}$ Unlike other nutritionally imbalanced foods, the energy content of mushrooms are low i.e. 360 $\mathrm{kcal} / \mathrm{kg}$ or $1506 \mathrm{~kJ} / \mathrm{kg}$ fresh mushrooms. ${ }^{25}$ In this regard, energy content of $L$. sulphureus has also been found to be less (Table 1) indicating that the mushroom is nutritionally optimized.

\section{Fibre}

Dietary fibre consists of remnants of food materials that are resistant to digestion and absorption in human small intestine. These non-digestible carbohydrate polymers include hemicellulose, cellulose, lignin, oligosaccharides, pectins, gums and waxes. Diets with a high content of fibre have beneficial physiological effect such as laxation, blood glucose attenuation, decreasing time of intestinal transit, trapping mutagenic agents, stimulating proliferation of intestinal flora and protecting cancer of large bowel. Therefore, there is a recent trend to search for novel sources of dietary fibre for utilization in food industry. ${ }^{26}$ To date, a few number of studies have reported fibre content of $L$. sulphureus that ranged from $7.157 \%$ to $4.12 \%$ DW (Table 1 ).

\section{Ash}

Ash is inorganic residue remaining after removal of water and organic matter by heating in presence of oxidizing agents. It provides a measurement of total quantity of minerals present within a food material. ${ }^{27}$ The reported values for ash content in L. sulphureus were found to be low and vary from 9.03 to $3.956 \mathrm{~g} / 100 \mathrm{~g}$ DW (Table 1).

\section{Minerals}

Minerals are inorganic chemical constituents of body that play important roles in construction of bone and tooth, oxygen transport, normal functioning of enzymes, hormones, nerve and muscle etc. In general, minerals are of two kinds such as macro (calcium, phosphorus, sodium, chlorine) and micro (iron, copper, cobalt, potassium, magnesium, iodine, zinc, manganese, fluorine, chromium, selenium, sulphur). As the name suggests, macro minerals are required in higher quantities $(>100 \mathrm{mg} / \mathrm{dl})$ while micro minerals are sufficient in lesser amounts $(<100 \mathrm{mg} / \mathrm{dl}) \cdot{ }^{29} \mathrm{In}$ case of mushrooms, usually potassium, phosphorus, sodium and magnesium comprise about $56-70 \%$ of total ash while potassium itself forms $45 \%$ of total ash content. ${ }^{18}$ Consequently, L. sulphureus has been proved to assimilate a number of minerals both macro as well as micro that might play important roles in human life. Table 2 summarizes mineral content of the macrofungi both wild and cultivated strains as published by different authors, although the values differ considerably.

\section{Vitamins}

Mushrooms are a good source of several vitamins, such as riboflavin, niacin, tocopherols (mainly $\gamma$-tocopherol) and folates with concentrations of $1.8-5.1,31-65$, and $0.30-0.64 \mathrm{mg} / 100 \mathrm{~g}$ DW respectively. It has been found that vitamin B2 content in macrofungi is higher than that obtained from vegetables and even equal to egg and cheese depending on species. However, the most potent provitamin A, $\beta$-carotene, has been detected to be less common in mushrooms. ${ }^{25}$ According to literature published, L. sulphureus may be considered as one of the best source of vitamins such as vitamin B, E and D. Petrović et al. (2014) gave a comprehensive data on vitamin content and have shown presence of different tocopherols in the order of $\alpha$-tocopherol $>\gamma$-tocopherol $>\delta$-tocopherol. ${ }^{4}$ However, vitamin B is also abundant in the macrofungi particularly B7, $\mathrm{B} 3, \mathrm{~B} 12$ and $\mathrm{B} 5 .^{22}$

\section{Organic acids}

Any organic carboxylic acid of general structure $\mathrm{R}-\mathrm{COOH}$ are considered to be organic acids. They are either simple mono-carboxylic acids such as formic, acetic, propionic and butyric acids or carboxylic acids consisting hydroxyl group including tartaric, malic, citric and lactic acids or carboxylic acids with double bonds like sorbic and fumaric acids. ${ }^{30}$ The content of different organic acids in L. sulphureus has been investigated which is summarized in Table 3.

\section{BIOACTIVE COMPOUNDS}

Besides providing essential macro and micro-nutrients to the body, L. sulphureus also delivers bioactive ingredients that possess health benefits. Among medically active primary metabolites, the most important are high molecular weight compounds such as polysaccharides, proteins and polysaccharide-protein complexes. Besides them, a large portion of reported biological activities is closely linked to secondary metabolites. About $75 \%$ of secondary metabolites are composed of triterpenoids with different structures, whereas other secondary metabolite classes are produced to a lesser extent. The second largest group of secondary metabolites $(\sim 14 \%)$ reported from the mushroom is composed of organic acids. L. sulphureus also contains other compounds belonging to different chemical classes, i.e. benzofurans, flavonoids, coumarins and $\mathrm{N}$-containing compounds. ${ }^{11}$

In general, investigations carried out on L. sulphureus show a combined study of evaluation of biological activity and myco-chemical composition. However, this tendency could not be observed in few cases. For instance, Olennikov et al. (2009) ${ }^{32}$ have extracted an alkali soluble polysaccharide, latiglucan I, although did not determine any biological activity. A mycophenolic acid derivative was isolated from cultures of the mushroom as well and determined structure by different spectroscopic data. The component was identified as 6-((2E, 6E)-3, 7-dimethyldeca-2, 6-dienyl)7-hydroxy-5-methoxy-4-methylphtanlan-1-one, although its medicinal potentials remain unexplored. ${ }^{33}$ Krzyczkowski et al. (2009) have isolated ergosterol peroxide from mycelia of the macrofungi without investigating on any activity. ${ }^{34}$ Another biologically undetermined component is $\mathrm{N}$-Phenethylhexadecanamide isolated from methanol extract of fruiting bodies. ${ }^{35}$ Alquini et al. (2004) isolated, purified and structurally characterized two main polysaccharides from this basidiomycetous fungus. One was a linear L-glucan having a (1C3)-linked main chain, namely laminaran, while the other was a fucomannogalactan. ${ }^{6}$ The bioactive properties of these polysaccharides still remain undiscovered.

\section{MEDICINAL ATTRIBUTES}

Despite lacking of research on several bioactive components, a vast number of medicinal properties of fruit bodies and mycelium of L. sulphureus have been discovered to date. As mentioned earlier, the macrofungus accumulate a variety of primary and secondary metabolites that are significantly correlated with bio-activities. For instance, phenolics are well known for their free radical scavenging, antiallergic, anti-atherogenic, anti-inflammatory, antimicrobial, anti-thrombic, cardio protective and 
Table 2: Content of selected macro and micro minerals in Laetiporus sulphureus

\begin{tabular}{|c|c|c|c|c|}
\hline $\begin{array}{l}\text { Type of } \\
\text { mineral }\end{array}$ & Mineral Name & Place of collection/Type of culture strain & $\begin{array}{c}\text { Quantity (mg/100 g } \\
\text { DW) }\end{array}$ & Reference \\
\hline \multirow[t]{20}{*}{ Macro } & Calcium & Hungarian Middle-Mountain & 76.5 & [3] \\
\hline & & Strain LS-BG-0804 & 1500 & [21] \\
\hline & & Strain LS-UK-0704 & 2170 & \\
\hline & & Black Sea Region (Turkey) & 420 & [19] \\
\hline & Phosphorus & Hungarian Middle-Mountain & 489 & {$[3]$} \\
\hline & & Strain LS-BG-0804 & 210 & [21] \\
\hline & & Strain LS-UK-0704 & 330 & \\
\hline & & Arunachal Pradesh & 56 & [28] \\
\hline & Magnessium & Sicily (southern Italy) & 107 & [19] \\
\hline & & Hungarian Middle-Mountain & 100.1 & [3] \\
\hline & & Strain LS-BG-0804 & 220 & [21] \\
\hline & & Strain LS-UK-0704 & 380 & \\
\hline & & Black Sea Region (Turkey) & 210 & [19] \\
\hline & Sodium & Hungarian Middle-Mountain & 20.99 & [3] \\
\hline & & Strain LS-BG-0804 & 80 & [21] \\
\hline & & Strain LS-UK-0704 & 80 & \\
\hline & & Arunachal Pradesh & 30 & {$[28]$} \\
\hline & & Black Sea Region (Turkey) & 28.5 & [19] \\
\hline & Potassium & Arunachal Pradesh & 600 & [28] \\
\hline & & Black Sea Region (Turkey) & 1.85 & [19] \\
\hline \multirow[t]{20}{*}{ Micro } & Iron & Hungarian Middle-Mountain & 5.09 & [3] \\
\hline & & Sicily (southern Italy) & 18 & [19] \\
\hline & & Strain LS-BG-0804 & 130 & [21] \\
\hline & & Strain LS-UK-0704 & 80 & \\
\hline & & Black Sea Region (Turkey) & 2.86 & [19] \\
\hline & Zinc & Strain MFLUCC 12-0546 & 0.12 & [2] \\
\hline & & Hungarian Middle-Mountain & 5.65 & [3] \\
\hline & & Strain LS-BG-0804 & 0.8 & [21] \\
\hline & & Strain LS-UK-0704 & 0.2 & \\
\hline & & Black Sea Region (Turkey) & 3.86 & [19] \\
\hline & Manganese & Strain MFLUCC 12-0546 & 0.035 & [2] \\
\hline & & Hungarian Middle-Mountain & 0.518 & [3] \\
\hline & & Black Sea Region (Turkey) & 0.5 & [19] \\
\hline & Copper & Strain MFLUCC 12-0546 & 0.014 & [2] \\
\hline & & Hungarian Middle-Mountain & 0.972 & [3] \\
\hline & & Black Sea Region (Turkey) & 0.28 & [19] \\
\hline & Silicon & Strain LS-BG-0804 & 230 & {$[21]$} \\
\hline & & Strain LS-UK-0704 & 80 & \\
\hline & Molybdenum & Strain LS-BG-0804 & 0.07 & [21] \\
\hline & & Strain LS-UK-0704 & 0.03 & \\
\hline
\end{tabular}


Table 3: Organic acids content in Laetiporus sulphureus

\begin{tabular}{|c|c|c|c|c|}
\hline Name of organic acid & \multicolumn{2}{|c|}{$\begin{array}{l}\text { Place of collection/ Type of fruiting bodies artificially } \\
\text { grown }\end{array}$} & Quantity (g/100 g DW) & Reference \\
\hline \multirow[t]{4}{*}{ Malic acid } & \multicolumn{2}{|c|}{ Black Sea Region (Turkey) } & 0.368 & [19] \\
\hline & LS-BG-0804 strain & Immature fruit body & 1.12 & {$[31]$} \\
\hline & & Ripened fruit body & 0.58 & \\
\hline & & Aged fruit body & 1.32 & \\
\hline Ascorbic acid & Black Sea Region (T & & 0.006 & [19] \\
\hline \multirow[t]{5}{*}{ Citric acid } & Black Sea Region ( $\mathrm{T}$ & & 0.0003 & [19] \\
\hline & Northern Serbia & & 1.24 & [4] \\
\hline & LS-BG-0804 strain & Immature fruit body & 0.45 & {$[31]$} \\
\hline & & Ripened fruit body & 0.56 & \\
\hline & & Aged fruit body & 1.48 & \\
\hline \multirow[t]{3}{*}{ Tartaric acid } & LS-BG-0804 strain & Immature fruit body & 1.39 & {$[31]$} \\
\hline & & Ripened fruit body & 1.3 & \\
\hline & & Aged fruit body & 1.52 & \\
\hline \multirow[t]{3}{*}{ Malonic acid } & LS-BG-0804 strain & Immature fruit body & 0.21 & {$[31]$} \\
\hline & & Ripened fruit body & 0.32 & \\
\hline & & Aged fruit body & 0.28 & \\
\hline \multirow[t]{3}{*}{ Succinic acid } & LS-BG-0804 strain & Immature fruit body & 0.1 & [31] \\
\hline & & Ripened fruit body & 0.35 & \\
\hline & & Aged fruit body & 0.45 & \\
\hline Oxalic acid & Northern Serbia & & 2.66 & [4] \\
\hline Fumaric acid & Northern Serbia & & 0.25 & \\
\hline Quinic acid & Northern Serbia & & 0.16 & \\
\hline
\end{tabular}

vasodilatory effects. ${ }^{36}$ Fungal lectins are widespread class of proteins that recognize carbohydrates and possess applications in cancer research, antimicrobial therapy and targeted drug delivery. ${ }^{37}$ In addition, polysaccharides (especially $\beta$-glucan) and polysaccharide-protein conjugates have been recognized to possess effective activities such as: anticancer, immunomodulatory, antiinflammatory and antioxidant. ${ }^{38}$

\section{Antioxidant}

Oxidative stress due to modern lifestyle and increase of average longevity are the key reasons for growing incidence of diseases especially radical induced ailments that have led to increase in demand for antioxidant products. Restriction on use of synthetic antioxidants has caused a rapid increase in requirements for natural alternative sources in which macrofungi are considered as a strong candidate. ${ }^{39}$ In past few years, L. sulphureus has attracted much attention as a potent commercial source of antioxidants and might be used to reduce oxidative stress. Table 4 summarizes evidences to support the effectiveness of such an approach in vitro.

To identify the antioxidant potential, Olennikov et al. (2011) subjected powdered fruit bodies to $70 \%$ ethanol and further fractionated the extract using several solvents such as hexane (LF-1), chloroform (LF-2), ethyl acetate (LF-3), butanol (LF-4) and water (LF-5). A water soluble crude polysaccharide was prepared (LF-6) using ethanol precipitation (1:10) and centrifugation. The supernatant was further concentrated to obtain another fraction namely LF-7. Chemical composition of these fractions showed that the maximal concentration of phenolic compounds and flavonoids were specific for LF-3 fraction which may influenced the highest antioxidant potential. Further detailed study on LF-3 identified seven bioactive components which were present in the order of: gallic acid $>$ chlorogenic acid $>$ caffeic acid $>p$-coumaric acid $>(+)$ catechin $>$ quercetin $>$ kaempferol. These extracted compounds were further evaluated for antioxidant activity where gallic acid possessed the most active 2,2-Diphenyl-1-picrylhydrazyl (DPPH) radical binding action and quercetin was more effective protector of $\beta$-carotene from peroxide destruction. ${ }^{13}$

Turkoglu et al. (2007) collected the mushroom from western part of Turkey and selected both young as well as old basidiocarps for preparation of ethanolic extract. The fraction exhibited dose dependent DPPH radical scavenging ability as it inhibited $14 \%, 26 \%, 55 \%$ and $86 \%$ at the concentrations of 100, 200, 400 and $800 \mu \mathrm{g} / \mathrm{ml}$ respectively. While, in respect with $\beta$-carotene/linoleic acid system, the extract showed $57.4 \%$ of inhibition at $80 \mu \mathrm{g} / \mathrm{ml}$ concentration that increased to $82.2 \%$ at $160 \mu \mathrm{g} / \mathrm{ml}$ concentration. The study also aimed at determining phenolic and flavonoid concentration where positive correlations were found between total phenolic content and antioxidant activities. ${ }^{40}$

In an another study, wild fruiting bodies naturally grown in Belgrade were subjected for preparation of three polysaccharide extracts namely hot water extract, partially purified polysaccharides and hot alkali extracted polysaccharides. Among these formulations, hot alkali extracted polysaccharide was the most active in respect to DPPH radical scavenging activity, reducing power and ferrous ion chelating ability. The fraction was consisted of the highest amount of a-glucan and total phenol content. A strong correlation was observed between $\alpha$-glucan and three antioxidant assays, while phenolic quantity contributed to DPPH radical scavenging and reducing power methods. ${ }^{5}$

Petrović et al. (2014) determined antioxidant activity of L. sulphureus inhabiting in Northern Serbia using two fractions such as methanol 
Table 4: Antioxidant activity of extracts prepared from fruit bodies of Laetiporus sulphureus as presented by the effective concentrations of extract that scavenges $50 \%$ of radical (EC50 values in $\mathrm{mg} / \mathrm{ml}$ ) 1. DPPH radical scavenging, 2 . Reducing power, 3.TBARS inhibition, 4 . $\beta$-Carotene bleaching inhibition, 5. Chelating ability of ferrous ion, 6 . Superoxide radical scavenging, 7. ABTS 8. Total antioxidant capacity by phosphomolybdenum method ( $\mu \mathrm{g} \mathrm{AAE} / \mathrm{mg}$ extract), 9. FRAP (mmol Trolox/kg DW). a Extract prepared from mycelium

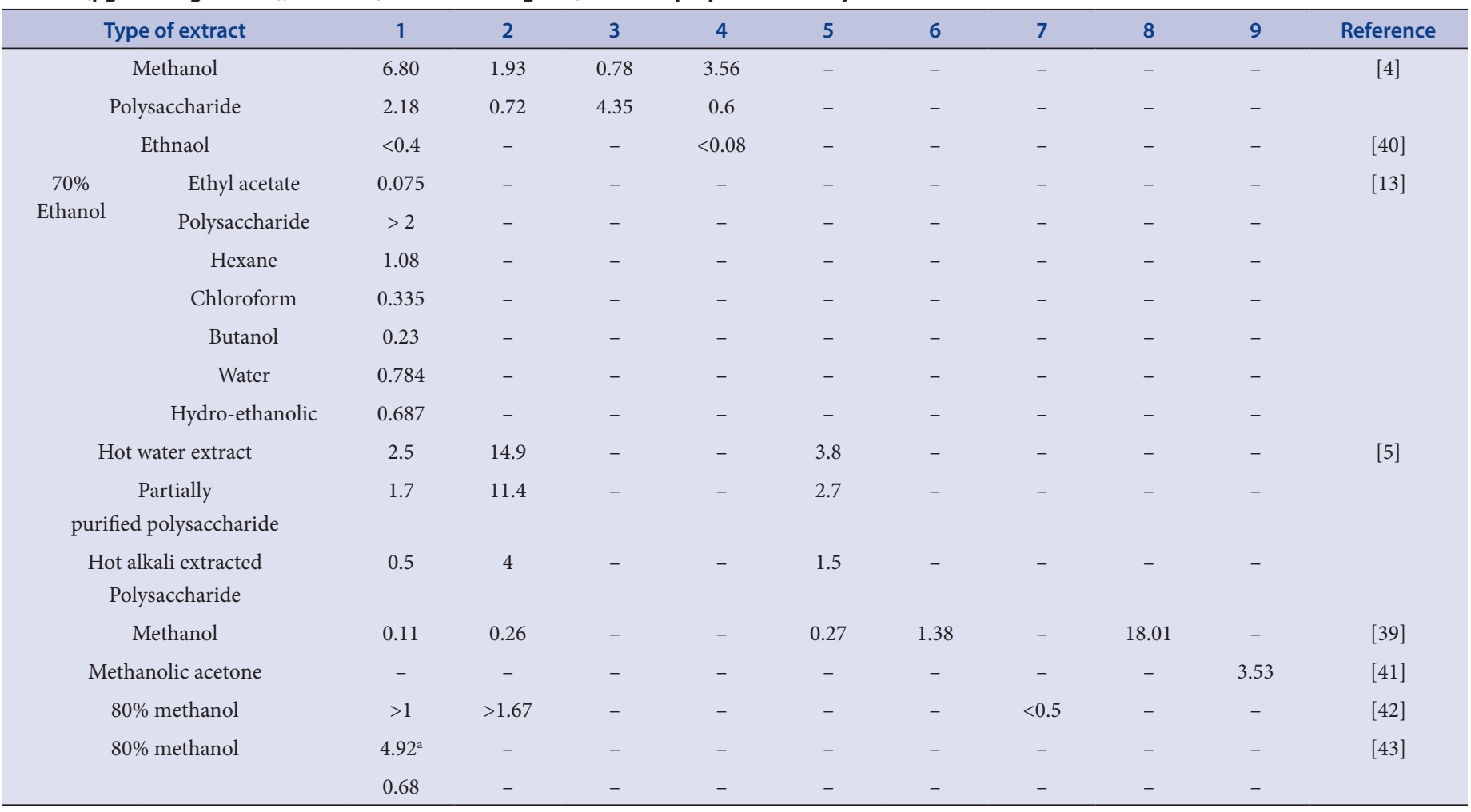

and crude polysaccharide prepared by hot water extraction method. Results exhibited that the polysaccharide fraction was more potent than methanol extract for DPPH radical scavenging activity, reducing power and $\beta$-carotene bleaching inhibition assays. While the methanol extract performed higher activity in thiobarbituric acid reactive substances (TBARS) inhibition method. $p$-Hydroxybenzoic acid and cinnamic acid were detected chromatographically in the methanol extract. ${ }^{4}$

Likewise, an additional study has been performed using methanol extract prepared from fruit bodies collected from India to determine antioxidant activity. The fraction showed potent activity in superoxide radical scavenging, DPPH radical scavenging, chelating ability of ferrous ion, reducing power and total antioxidant assays where $\mathrm{EC}_{50}$ values ranged from 0.11 to $1.38 \mathrm{mg} / \mathrm{ml}$ concentration. In addition, the fraction was determined to be composed of different bioactive compounds such as phenolics, flavonoids, carotenoids and ascorbic acid. Moreover, preliminary chemical screening detected presence of cardiac glycoside, flavonoid, phenol, saponin and terpenoids. ${ }^{39}$

Sulkowskan-Ziaja et al. (2012) performed a comparative study on chemical composition and antioxidant activity of polyporoid mushrooms including L. sulphureus. They collected the fruit bodies from southern Poland and quantified bioactive compounds with special emphasis on phenolic acids. Results showed presence of moderate amount of phenolic compounds i.e. $10.4 \mathrm{mg}$ gallic acid equivalent/g DW. In addition, HPLC chromatogram revealed existence of protocatechuic acid where $p$-hydroxybenzoic acid and vanillic acid were present in minor amounts. Further, antioxidant activity by FRAP assay indicated moderate potentials of the fungus. ${ }^{41}$

Likewise, another comparative evaluation has been reported determining antioxidant activities of $80 \%$ aqueous methanol extract of total 33 mushrooms collected from Deogyu Mountain, Korea. In case of
2,2'-Azinobis(3-Ethylbenzthiazoline-6-Sulfonate) (ABTS) radical scavenging assay, the extract of $L$. sulphureus var miniatus exhibited more than $60 \%$ inhibition at $0.5 \mathrm{mg} / \mathrm{ml}$ concentration which was found to be higher than 25 experimented specimens. The extract also scavenged $>40 \%$ of DPPH radicals at $1 \mathrm{mg} / \mathrm{ml}$ concentration and the potentials was better than 30 specimens under investigation. While in another assay, the fraction presented $>0.4$ reducing power at $1.67 \mathrm{mg} / \mathrm{ml}$ concentration and indicated higher function than 29 considered mushrooms. ${ }^{42}$

In a similar study, Prasad et al. (2015) investigated on antioxidant activity and total phenolic content of the mushroom along with other 15 Basidiomycetes collected from natural forests near Dehradun, India. They subjected fruiting bodies and submerged cultured mycelia to $80 \%$ methanol solvent and compared the results. Analysis showed that fruiting bodies of $L$. sulphureus had more potent DPPH radical scavenging activity than mycelia of other studied species. In addition, the mushroom presented better antioxidant potentials than 9 other macrofungi examined. Presence of higher amount of phenolics might had played a key role behind such activity. ${ }^{43}$

Olennikov et al. (2009) isolated Laetiporan A, the major $56-\mathrm{kDa}$ polysaccharide of the mushroom, that was found to be comprised of a $\beta$-1,3-glucan containing mannose, galactose, fucose, xylose and rhamnose residues at position $\mathrm{C}-6$. The pure polysaccharide showed prevention of liver lesion in toxic hepatitis model by executing strong antioxidant effect on lipid peroxidation. Administration of laetiporan A resulted in significant decrease in the level of malonic dialdehyde and conjugated dienes in animals suffering from carbon tetrachloride $\left(\mathrm{CCl}_{4}\right)$ induced

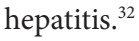


Table 5: Antibacterial activity of Laetiporus sulphureus. The results are presented in zone size detected by agar well diffusion method and minimum inhibitory (MIC) as well as minimum bactericidal (MBC) concentrations determined by microdilution method. (E224 indicates extract type in combination with $0.01 \mathrm{M}$ potassium disulfite, a food additive).

\begin{tabular}{|c|c|c|c|c|c|c|}
\hline $\begin{array}{c}\text { Type of } \\
\text { bacteria }\end{array}$ & Name of bacteria & Extract & Zone size $(\mathrm{mm})$ & $\mathrm{MIC}(\mathrm{mg} / \mathrm{ml})$ & $\begin{array}{c}\mathrm{MBC}(\mathrm{mg} / \\
\mathrm{ml})\end{array}$ & Reference \\
\hline \multirow{43}{*}{$\begin{array}{c}\text { Gram } \\
\text { negative }\end{array}$} & Pseudomonas aeruginosa & Ethanol & 6 & & & [40] \\
\hline & & n-Hexane & & 1.5 & 2 & [47] \\
\hline & & Chloroform & & 1.56 & 3.125 & \\
\hline & & Methanol & & 2.8 & 3.6 & {$[4]$} \\
\hline & & Polysaccharide & & 1.5 & 3.1 & \\
\hline & & Methanol & & 20 & 30 & {$[46]$} \\
\hline & & Methanol + E 224 & & 5 & 10 & \\
\hline & & Acetone & & 5 & 10 & \\
\hline & & Acetone + E 224 & & 2.5 & 5 & \\
\hline & & $\mathrm{DCM}$ & & 10 & 20 & \\
\hline & & $\mathrm{DCM}+\mathrm{E} 224$ & & 5 & 10 & \\
\hline & Salmonella enteritidis & Ethanol & 5 & & & [40] \\
\hline & & Methanol & & 0.63 & 1.25 & [46] \\
\hline & & Methanol + E 224 & & 0.31 & 0.63 & \\
\hline & & Acetone & & 5 & 10 & \\
\hline & & Acetone + E 224 & & 5 & 10 & \\
\hline & & $\mathrm{DCM}$ & & 5 & 10 & \\
\hline & & $\mathrm{DCM}+\mathrm{E} 224$ & & 2.5 & 5 & \\
\hline & Escherichia coli & Ethanol & 10 & & & [40] \\
\hline & & n-Hexane & & 2 & 4 & [47] \\
\hline & & Chloroform & & 1.56 & 3.125 & \\
\hline & & Methanol & & 2.8 & 3.6 & {$[4]$} \\
\hline & & Polysaccharide & & 1.5 & 3.1 & \\
\hline & & Methanol & & 20 & 30 & [46] \\
\hline & & Methanol + E 224 & & 10 & 20 & \\
\hline & & Acetone & & 10 & 20 & \\
\hline & & Acetone + E 224 & & 5 & 10 & \\
\hline & & $\mathrm{DCM}$ & & 10 & 20 & \\
\hline & & $\mathrm{DCM}+\mathrm{E} 224$ & & 5 & 10 & \\
\hline & Morganella morganii & Ethanol & 4.5 & & & [40] \\
\hline & Yersinia enterocolitica & Ethanol & 6 & & & \\
\hline & Klebsiella pneumoniae & Ethanol & No inhibition & & & \\
\hline & Proteus vulgaris & Ethanol & 5.5 & & & \\
\hline & Salmonella typhimurium & Methanol & & 0.9 & 1.8 & {$[4]$} \\
\hline & & Polysaccharide & & 0.4 & 4.8 & \\
\hline & & n-Hexane & & 0.15 & 0.3 & [46] \\
\hline & & Chloroform & & 0.78 & 3.125 & \\
\hline & & Methanol & & 5 & 10 & [46] \\
\hline & & Methanol + E 224 & & 1.25 & 2.5 & \\
\hline & & Acetone & & 5 & 10 & \\
\hline & & Acetone + E 224 & & 5 & 10 & \\
\hline & & $\mathrm{DCM}$ & & 5 & 10 & \\
\hline & & $\mathrm{DCM}+\mathrm{E} 224$ & & 1.25 & 2.5 & \\
\hline
\end{tabular}

Continued... 


\section{Table 5: Cont'd.}

\begin{tabular}{|c|c|c|c|c|c|c|}
\hline $\begin{array}{r}\text { Type of } \\
\text { bacteria }\end{array}$ & Name of bacteria & Extract & Zone size (mm) & $\mathrm{MIC}(\mathrm{mg} / \mathrm{ml})$ & $\begin{array}{l}\mathrm{MBC}(\mathrm{mg} / \\
\mathrm{ml})\end{array}$ & Reference \\
\hline \multirow[t]{45}{*}{ Gram positive } & Staphylococcus aureus & Ethanol & 9 & & & {$[40]$} \\
\hline & & n-Hexane & & 0.25 & 0.5 & {$[47]$} \\
\hline & & Chloroform & & 0.4 & 0.78 & \\
\hline & & Methanol & & 1.8 & 3.6 & {$[4]$} \\
\hline & & Polysaccharide & & 0.4 & 2.4 & \\
\hline & & Methanol & & 0.63 & 1.25 & {$[46]$} \\
\hline & & Methanol + E 224 & & 0.31 & 0.63 & \\
\hline & & Acetone & & 5 & 10 & \\
\hline & & Acetone + E 224 & & 2.5 & 5 & \\
\hline & & DCM & & 1.25 & 2.5 & \\
\hline & & $\mathrm{DCM}+\mathrm{E} 224$ & & 0.63 & 1.25 & \\
\hline & $\begin{array}{c}\text { Staphylococcus aureus } \\
\text { Cowan I }\end{array}$ & Ethanol & 7 & & & {$[40]$} \\
\hline & Micrococcus luteus & Ethanol & 15 & & & \\
\hline & Micrococcus flavus & Ethanol & 23 & & & \\
\hline & & n-Hexane & & 1 & 2 & [47] \\
\hline & & Chloroform & & 0.78 & 1.56 & \\
\hline & & Methanol & & 1.4 & 1.8 & {$[4]$} \\
\hline & & Polysaccharide & & 3.1 & 6.2 & \\
\hline & & Methanol & & 20 & 30 & [46] \\
\hline & & Methanol + E 224 & & 2.5 & 10 & \\
\hline & & Acetone & & 20 & 30 & \\
\hline & & Acetone + E 224 & & 5 & 10 & \\
\hline & & DCM & & 10 & 20 & \\
\hline & & $\mathrm{DCM}+\mathrm{E} 224$ & & 10 & 20 & \\
\hline & & Aqueous & & 1.5 & & [45] \\
\hline & Bacillus subtilis & Ethanol & 8 & & & {$[40]$} \\
\hline & Bacillus cereus & Ethanol & 12 & & & \\
\hline & & Methanol & & 1.25 & 2.5 & [46] \\
\hline & & Methanol + E 224 & & 1.25 & 2.5 & \\
\hline & & Acetone & & 2.5 & 5 & \\
\hline & & Acetone + E 224 & & 2.5 & 5 & \\
\hline & & DCM & & 2.5 & 5 & \\
\hline & & $\mathrm{DCM}+\mathrm{E} 224$ & & 1.25 & 2.5 & \\
\hline & Candida albicans & Ethanol & 21 & & & \\
\hline & Listeria monocytogenes & Methanol & & 3.6 & 7.2 & {$[4]$} \\
\hline & & Polysaccharide & & 3.1 & 6.2 & \\
\hline & & n-Hexane & & 0.9 & 3.6 & [47] \\
\hline & & Chloroform & & 1.56 & 3.125 & \\
\hline & & Methanol & & 10 & 20 & [46] \\
\hline & & Methanol + E 224 & & 2.5 & 5 & \\
\hline & & Acetone & & 5 & 10 & \\
\hline & & Acetone + E 224 & & 2.5 & 5 & \\
\hline & & $\mathrm{DCM}$ & & 2.5 & 5 & \\
\hline & & $\mathrm{DCM}+\mathrm{E} 224$ & & 1.25 & 2.5 & \\
\hline & & Aqueous & & 1.5 & & {$[45]$} \\
\hline
\end{tabular}


Table 6: Anticancer activity of Laetiporus sulphureus with IG ${ }_{50}$ values (drug concentration inhibiting $50 \%$ of cell growth). Treatment duration with the components is being indicated within brackets.

\begin{tabular}{|c|c|c|c|}
\hline Name of cancer cell & Extract/ active component & $\mathrm{IG}_{50}$ & Reference \\
\hline Human T4 leukemic & Ethanol & 0.7 & [51] \\
\hline \multirow[t]{3}{*}{ Hela cervical } & Ethanol & Inactive & \\
\hline & Methanol & $>400 \mu \mathrm{g} / \mathrm{ml}$ & {$[4]$} \\
\hline & Polysaccharide & $72.26 \mu \mathrm{g} / \mathrm{ml}$ & \\
\hline \multirow[t]{3}{*}{ MCF-7 } & Methanol & $>400 \mu \mathrm{g} / \mathrm{ml}$ & \\
\hline & Polysaccharide & $239.57 \mu \mathrm{g} / \mathrm{ml}$ & \\
\hline & 6-((2E, 6E)-3, 7, 11-trimethyldedoca-2, 6, 10-trienyl)-5, 7-dihydroxy-4-methylphtanlan-1-one & $35.7 \mu \mathrm{mol} / \mathrm{L}$ & [33] \\
\hline \multirow[t]{2}{*}{ NCI-H460 } & Methanol & $>400 \mu \mathrm{g} / \mathrm{ml}$ & {$[4]$} \\
\hline & Polysaccharide & $181.49 \mu \mathrm{g} / \mathrm{ml}$ & \\
\hline \multirow[t]{2}{*}{ HCT15 } & Methanol & $>400 \mu \mathrm{g} / \mathrm{ml}$ & \\
\hline & Polysaccharide & $68.96 \mu \mathrm{g} / \mathrm{ml}$ & \\
\hline \multirow[t]{2}{*}{ HepG2 } & Methanol & $>400 \mu \mathrm{g} / \mathrm{ml}$ & \\
\hline & Polysaccharide & $>400 \mu \mathrm{g} / \mathrm{ml}$ & \\
\hline \multirow[t]{3}{*}{ Kato III } & Egonol & $28.8 \mu \mathrm{g} / \mathrm{ml}$ & [54] \\
\hline & Demethoxyegonol & $27.5 \mu \mathrm{g} / \mathrm{ml}$ & \\
\hline & Egonol glucoside & $24.9 \mu \mathrm{g} / \mathrm{ml}$ & \\
\hline \multirow[t]{8}{*}{ HL-60 } & 6-((2E, 6E)-3, 7, 11-trimethyldedoca-2, 6, 10-trienyl)-5, 7-dihydroxy-4-methylphtanlan-1-one & $39.1 \mu \mathrm{mol} / \mathrm{L}$ & [33] \\
\hline & 3-oxo-sulfurenic acid & $407 \mu \mathrm{M}(96 \mathrm{~h})$ & [58] \\
\hline & Acetyl derivative of 3-oxo-sulfurenic acid & $25 \mu \mathrm{M}(96 \mathrm{~h})$ & \\
\hline & Eburicoic acid & $25 \mu \mathrm{M}(96 \mathrm{~h})$ & \\
\hline & Sulfurenic acid & $14 \mu \mathrm{M}(96 \mathrm{~h})$ & \\
\hline & Acetyl eburicoic acid & $15 \mu \mathrm{M}(96 \mathrm{~h})$ & \\
\hline & Acetyl tram-etenolic acid & $31 \mu \mathrm{M}(96 \mathrm{~h})$ & \\
\hline & $15 a$-hydroxytrametenolic acid & $12 \mu \mathrm{M}(96 \mathrm{~h})$ & \\
\hline SMMC-7721 & 6-((2E, 6E)-3, 7, 11-trimethyldedoca-2, 6, 10-trienyl)-5, 7-dihydroxy-4-methylphtanlan-1-one & $31.1 \mu \mathrm{mol} / \mathrm{L}$ & [33] \\
\hline A-549 & 6-((2E, 6E)-3, 7, 11-trimethyldedoca-2, 6, 10-trienyl)-5, 7-dihydroxy-4-methylphtanlan-1-one & $27.4 \mu \mathrm{mol} / \mathrm{L}$ & \\
\hline $\mathrm{U}-87 \mathrm{MG}$ & Sulphureuine B & $16 \mu \mathrm{M}(24 \mathrm{~h})$ & [59] \\
\hline
\end{tabular}

\section{Antimicrobial}

Mushrooms are considered to be a rich source of antibacterial and antifungal compounds as they need them to survive in natural environment. Thus, it is not surprising that antimicrobial compounds isolated from mushrooms could be useful for human benefit. ${ }^{44}$ In this context, many research groups have investigated on the evaluation of antimicrobial effects of $L$. sulphureus with special emphasis on antibacterial activity (Table 5).

Recently, Petrović et al. (2014) prepared three fractions of the fruiting bodies collected from Serbia namely aqueous methanol, methanol and ethanol extracts obtained after application of classical and ultrasound extraction methods. All fractions presented high potentials to inhibit growth of microbes while extracts obtained by ultrasound technique were proved to be more potent than that of classical extract. Interestingly, in some cases the activity of methanolic and ethanolic formulations prepared by ultrasound technique exceeded that of commercial antibiotics. ${ }^{4}$ In a separated study, ethanol extract was used to determine antimicrobial effect where several species of Gram-positive bacteria, Gram-negative bacteria and yeast were selected as experimental pathogens. Results showed that the extract had a narrow antibacterial spectrum against Gram negative bacteria, though strongly inhibited growth of examined
Gram-positive bacteria. However, the fraction did not show any activity against Klebsiella pneumoniae at the evaluated concentrations. ${ }^{40}$

Šiljegović et al. (2011) used four species of Gram negative bacteria, four species of Gram positive bacteria and seven species of fungi to detect antimicrobial effect of aqueous extract from the mushroom. The fractions exhibited excellent potentials against all tested fungi with $0.3 \mathrm{mg} / \mathrm{ml}$ as minimum fungicidal concentration (MFC). While in case of bacteria, the extract was able to inhibit only Micrococcus flavus and Listeria monocytogenes with minimum inhibitory concentration (MIC) of $1.5 \mathrm{mg} / \mathrm{ml}$. Overall, the extract exhibited better antifungal than antibacterial activity, as the fraction showed insufficient inhibitory action against the remaining bacterial strains at concentration range of $0.15-1.5 \mathrm{mg} / \mathrm{ml} .{ }^{45}$

A comparative study on antimicrobial activity of methanol, acetone and dichloromethane extracts from L. sulphureus in combination with and without food additive, E224, have been investigated by Petrović et al. (2013). Results indicated that methanol extract possessed the best activity against all tested bacteria with exception of Escherichia coli. While, evaluation of antifungal activity of all three selected extracts without addition of E224 showed the best inhibitory activity for methanol fraction. In general, methanol extract again exhibited the best fungicidal activity with exception for three fungi: Aspergillus flavus, Aspergillus niger and Aspergillus fumigatus. ${ }^{46}$ 
In another experiment, Petrović et al. (2014) isolated two fractions from the mushroom namely methanol and polysaccharide formulations. The polysaccharidic extract showed higher antibacterial activity than methanolic extract, except M. flavus and Salmonella typhimurium. The same feature was observed for antifungal properties, with exception of Penicillium ochrochloron. Comparing antibacterial and antifungal activities of the tested extracts, it could be noted that bacteria were more sensitive to both extracts than fungi. ${ }^{4}$

Besides, Beauvericin, an antimicrobial secondary metabolite, has been detected in L. sulphureus. The component is considered as a mycotoxin produced by hypocrealean ascomycetes in grain. Moreover, it also possesses insecticidal and nematocidal activity. ${ }^{12}$

\section{Anti-HIV}

In contrast to bacterial infectious diseases, specific drugs are urgently needed to treat viral diseases as they cannot be cured by common antibiotics. ${ }^{44}$ In view of that, Mlinarič et al. (2005) prepared methanol and dichloromethane extracts from 57 species of wood damaging fungi and investigated for their ability to inhibit HIV-1 reverse transcriptase activity. The member with outstanding activity was $L$. sulphureus with inhibitory potentials of $90.1 \%$. However, methanolic extract was found to be superior to that of dichloromethane formulation. Furthermore, the potent fraction was analysed by preparative HPLC where 5 fractions were collected and tested for inhibitory action. The most active fraction, namely fraction 1 , was analysed by thin layer chromatography and findings confirmed presence of an acidic compound with amino group. ${ }^{48}$

\section{Anti-malaria}

Malaria is one of the most threatening diseases especially in tropical world as it causes hundreds of millions of illnesses and hundreds of thousands of deaths in each year. Parasitic resistance to drugs have limited the efficacies of many antimalarial drugs suggesting search of the newest drugs. ${ }^{49}$ However, a novel class of antimalarial agent has been detected in L. sulphureus that confirmed activity against HBO strain of Plasmodium falciparum (a malarial parasite). In detail, two extracts such as dimethyl sulfoxide and ethanol fractions were prepared from the fruit bodies that exhibited $0.6 \%$ and $2.4 \%$ inhibition respectively. Thus the mushroom presented an advantageous characteristic of potential antimalarial drugs. ${ }^{50}$

\section{Anticancer}

According to World Health Organization, an estimated 12.7 million people were diagnosed with cancer globally that caused death of about 7.6 million people in 2008. It has been also estimated that, by 2030 more than 21 million new cancer cases and 13 million deaths will be predicted. ${ }^{51}$ However, the available current anticancer drugs are not target specific and in contrary have demonstrated to cause several side effects. Therefore, the scenario highlights serious need for novel effective and less toxic agents mainly from natural products. As such, medicinal mushrooms and their derivatives are expected to play an important role in prevention of human cancer by developing innovative agents. ${ }^{52}$ In this context, L. sulphureus with validated anticancer properties and its active compounds are of immense interest (Table 6).

The research conducted by Yin et al. $(2015)^{53}$ directed to isolation of four lanostane-type triterpenes including three new ones, namely 15a-hydroxy-3,4-secolanosta-4(28),8,24-triene-3,21-dioic acid, 5a-hydroxy -3,4-seco-lanosta-4(28),8,24-triene-3,21-dioic acid 3-methyl ester, 15 a-acetoxyltrametenolic acid and a known one versisponic acid D from L. sulphureus var. miniatus. All four compounds were evaluated for their cytotoxicity activity against MCF-7, SMMC-7721, HL-60, SW480 and A-549 cells using 3-(4,5-dimethylthiazol-2-yl)-2,5-diphenyltetrazolium bromide (MTT), although none of the compounds showed activity.
Four components were isolated from ethanol extract of fresh fruiting bodies of L. sulphureus var. miniatus from needle leaf tree. The compounds were identified as egonol, demethoxyegonol, egonol glucoside and egonol gentiobioside. Some of these compounds exhibited cytotoxicity against Kato III cells. ${ }^{54}$ Fan et al. (2014) isolated three mycophilic acid derivative from cultures of L. sulphureus. Among them, 6-((2E, 6E)-3, 7, 11-trimethyldedoca-2, 6, 10-trienyl)-5, 7-dihydroxy-4-methylphtanlan-1-one exhibited moderate cytotoxicity against HL-60, SMMC-7721, A-549 and MCF-7 cells. ${ }^{33}$

He et al. (2015) discovered a novel natural component from culture of L. sulphureus. The compound was an illudin type sesquiterpenoid and named as sulphureuine $\mathrm{A}$ (molecular formula $\mathrm{C}_{15} \mathrm{H}_{22} \mathrm{O}_{2}$ ). It was tested for cytotoxic activities against human tumor cell lines HL-60, SMMC-7721, A549, MCF-7 and SW480, although, no significant inhibitory activity was detected $\left(\mathrm{IC}_{50}>40 \mathrm{mM}\right){ }^{55}$

Petrović et al. (2013) have isolated two fractions from the mushroom namely methanol extract and polysaccharide fraction to investigate for antiproliferative activity against human tumor cell lines. The results indicated that polysaccharide extract was the only one that showed activity. It did not exhibit activity against HepG2 cell line, in contrast to HCT15 and HeLa which were found to be the most susceptible cell lines. However, none of the extracts were determined to be toxic for porcine liver cells. ${ }^{46}$ A crude water insoluble and alkali soluble polysaccharide was isolated from fruit bodies of the mushroom inhabiting in Poland. Cytotoxic activity of the polysaccharide was measured by MTT and neutral red assays against HeLa, Jurkat and HSF cells. After $48 \mathrm{~h}$ incubation, HeLa cell viability in treatment with the glucan was $80 \%$ regardless of concentration, while the polysaccharide decreased viability of Jurkat cells by $30 \%$. Although a high viability and proliferative activity of normal cells was detected. ${ }^{56}$

By virtue of a reverse-immunoaffinity system $( \pm)$ Laetirobin was isolated from L. sulphureus parasitically grown on black locust tree, Robinia pseudoacacia. The component was screened for activity against HeLa, HCT116 and Neuro-2a cell lines. Preliminary studies indicated the cytotoxic activity by entering rapidly inside tumour cells, blocking cell division at late phase of mitosis that resulted in apoptosis. ${ }^{57}$

León et al. (2004) isolated and characterized a new lanostane triterpene, 3-oxo-sulfurenic acid, along with six other known compounds isolated from the fungus from Colombia. They assessed cytotoxicity of the seven triterpenoids on HL-60 cell lines and after $96 \mathrm{~h}$ observed that all these compounds suppressed proliferation of cancer cell at very low concentration. Further analysis in detail indicated that the components triggered morphological changes and DNA fragmentation which are hallmark of apoptosis. The mechanism of action was mediated through intrinsic pathway by activating Caspase- 3 ad releasing cytochrome c. ${ }^{58}$

A drimane type sesquiterpenoids, sulphureuine $B$, was isolated from the edible mushroom and its antiproliferative properties were investigated using U-87MG glioma cells. The component performed as a favourable antiproliferative agent by inducing membrane swelling, nuclear fragmentation, and vacuolisation of cytoplasm, endoplasmic reticulum stress and loss of mitochondrial membrane integrity. Results of western blotting clearly disclosed procaspase-3, -8 and -9 decrease and significant elevation in cleaved caspase- 3 , caspase- 8 and caspase- 9 , suggesting caspase activation. ${ }^{59}$

\section{Anti-ulcer}

The most common disorder of upper digestive tract is gastric ulcer and the annual prevalence of the disease ranges from $0.1-0.19 \%$ of population. Current therapeutic regimens demonstrated that herbal medicines exhibit therapeutic benefits by stimulation of mucous cell, inhibition gastric acid secretion and retardation of $\mathrm{H}(+) / \mathrm{K}(+)$ ATPase 
activity. Moreover, the cost of western medicine is about six times higher than that of herbal drugs for gastric ulcer. Thus, a valuable alternative to treat the disease in humans is utilization of herbal formulations that are effective in healing experimentally induced gastric ulcer. ${ }^{60}$

Wang et al. (2015) investigated on antiinflammatory and tumor inhibiting effects of eburicoic acid, the main bioactive component in L. sulphureus, on gastric ulcers. The results showed that oral administration of eburicoic acid protected gastric mucosa from gastric lesions morphologically and especially attenuated $\mathrm{H}+/ \mathrm{K}+$-ATPase activity. Computer aided molecular docking simulated interaction between eburicoic acid and $\mathrm{H}+/ \mathrm{K}+-$ ATPase. The study indicated that gastric protective effect of eburicoic acid might inhibit gastric acid. ${ }^{61}$

\section{Hepatoprotective}

Liver damage is a widespread disease and may be caused by many xenobiotics such as alcohol, many medicines, malnutrition, infection and anaemia. Consequently, the hepatic injury results in an increase in serum concentration of aminotransferases: aspartate aminotransferase (AST) and alanine aminotransferase (ALT). ${ }^{62}$ Despite availability of synthetic drugs in market, prolonged use of them may cause side effects. Therefore, extensive research is needed to find safe and cost effective drug. ${ }^{63}$

Recently, Sun et al. (2014) isolated eburicoic acid and trametenolic acid B from L. sulphureus and evaluated their hepatoprotective activity using Sprague-Dawley rats. They made hepatic fibrosis models induced by $\mathrm{CCl}_{4}$ and evaluated content of AST and ALT, levels of liver cell injury and degree of liver fibrosis. Results indicated that the treatment caused significant decrease of serum AST and ALT, improvement of liver cell damage, reduction of collagen deposition in liver tissue and subsequently inhibition of liver fibrosis. Therefore, the study indicated that eburicoic acid and trametenolic acid $\mathrm{B}$ are beneficial to execute hepatoprotective effects on $\mathrm{CCl}_{4}$ induced hepatic fibrosis. ${ }^{64}$

\section{Anti-inflammation}

Inflammation is a part of non-specific immune response that causes alteration in blood flow, vascular permeability and destruction of tissues. After exposure of immune stimulants, pro-inflammatory cells initiate the inflammation process by producing various biomarkers such as IL- $1 \beta$, IL-6, IL-8, TNF- $\alpha$, nuclear factor- $\kappa \mathrm{B}$, COX-2, prostaglandin $\mathrm{E}_{2}$, and inducible nitric oxide synthase (iNOS) which produces nitric oxide. Overproduction of these mediators promote diseases such as juvenile idiopathic arthritis, inflammatory rheumatoid arthritis, gastritis, bronchitis and atherosclerosis. Till date, treatments are not able to solve these disorders suggesting finding of new antiinflammatory therapeutic compounds..$^{65}$

To discover biologically active antiinflammatory compounds from wood rotting fungi, Saba et al. (2015) have isolated a triterpene, LSMH7, from fruiting bodies of L. sulphureus var. miniatus inhabiting in Mt. Odae, Gangwon Province, Korea. The chemical structure of LSM-7 was identified as acetyl eburicoic acid as interpreted by sophisticated instruments. Results demonstrated that LSM-H7 dose dependently inhibited NO production, although did not show any cytotoxic effects over investigated dosage range $(12.5,25,50,100 \mu \mathrm{g} / \mathrm{ml})$. Furthermore it suppressed production of proinflammatory cytokines, mainly iNOS, COX-2, IL-1 $\beta$, IL-6 and TNF- $\alpha$. These data suggested LSM-H7 as a crucial component for antiinflammatory activity of $L$. sulphureus var. miniatus. $^{66}$

\section{Immunomodulatory}

Immunomodulators are effective agents for stimulating leukocytes, cells of macrophage system to modulate immune system of body. Constant addition of these components to feed has been recommended for preventing diseases originating from certain immune-deficiencies and other depressed states of immunity. Various substances with immunomodulatory activity have been isolated from mushrooms which include mainly polysaccharides (in particular $\beta$-D-glucans), polysaccharopeptides, polysaccharide proteins, and proteins. Therefore, these metabolites might be applied for the treatment of immunodeficiency diseases. ${ }^{67}$

In this context, an extracellular polysaccharide was isolated from mycelial cultures of $L$. sulphureus var. miniatus consisting of a main chain with $(1 \rightarrow 4)$-Glcp units branching at C-6 position of the chain carrying -Glcp$(1 \rightarrow 4)$-linked residues with molecular mass of $6.95 \mathrm{kDa}$. Effect of the polysaccharide on immunomodulatory genes and proteins of Bcl-2 family was observed using cultured U937 human leukemia cells. Of note, levels of Bax and Bad proteins treated with the pure component were approximately two times higher in comparison with control cells. The results may suggest that the polysaccharide is associated with activation of immunomodulatory mediators, Bax and Bad proteins. ${ }^{68}$

\section{Anti-diabetic}

Diabetes mellitus is a chronic metabolic disease that originates due to improper functioning of insulin and results in increase in blood sugar level. Recent discoveries have opened a novel way to control the disorder by developing therapeutics from medicinal mushrooms as they function by inhibiting glucose absorption, protecting beta-cell damage, increasing insulin release, enhancing antioxidant defence, attenuating inflammation, modulating carbohydrate metabolism pathway and regulating insulin dependent as well as insulin independent signalling pathways. ${ }^{69}$

Glucose lowering effect of crude extracellular polysaccharides produced from submerged mycelial culture of $L$. sulphureus var. miniatus has been investigated in Streptozotocin (STZ)-induced diabetic rat and results exhibited its excellent hypoglycemic effect. The polysaccharide extract was orally administrated after $48 \mathrm{~h} \mathrm{STZ} \mathrm{treatment} \mathrm{and} \mathrm{resulted} \mathrm{in} \mathrm{lowering}$ plasma level of glucose, total cholesterol and triglyceride to near-normal state. Furthermore, immune-histochemical staining of pancreatic tissues suggested possibility of $\beta$-cell proliferation or regeneration by the therapy as treatment considerably increased insulin antigenesity of diabetic islet $\beta$-cells. Moreover, the polysaccharide fraction treatment revealed neutralization of alleviated oxidative stress mediated by STZ by increasing iNOS, superoxide dismutase 2, catalase, glutathione peroxidase as determined by immunoblotting study. In summary, the polysaccharide fraction may be useful for treatment and management of diabetes mellitus. ${ }^{70}$

Dehydrotrametenolic acid has been found in several polypores including L. sulphureus. It reduces hyperglycemia in mice with noninsulin dependent diabetes mellitus and acts as an insulin sensitizer in glucose tolerance tests. $^{12}$

\section{Anti-thrombin}

Okamura et al. (2000) screened higher Basidiomycetes for anti-thrombin activity where L. sulphureus was chosen as one of the most active member. To avoid cultivation of the fungus, they used protoplast fusion between L. sulphureus and Hypsizygus marmoreaus, a commonly cultivated Basidiomycete. The cultivable fusants produced an anti-thrombin substance which was safe unlike other synthetic substances. Thus, use of these fusant mushrooms as food may help prevent thrombosis in future. ${ }^{71}$

\section{CONCLUSIONS AND FUTURE PERSPECTIVES}

It is evident that L. sulphureus has been considered as an ingredient of ethnic cuisines and medicines across the globe. Therefore, it can be easily assumed that inclusion of this cosmopolitan mushroom into our lifestyle may benefit us. The concept has provided a major impetus that increased scientific attention in the last few decades in search of potential uses. As investigation expands, the species has revealed presence of essential nutrients and can be used in low-calorie diets. In contrary, there is 
limited information on bioavailability, moisture quantity, caloric value, amino acid composition and vitamin content. However, use of this sustainable food source in our daily diet is not popular suggesting lack of knowledge and awareness. Thus nutritional benefits of the mushroom need to be expanded from common people to health conscious public which will encourage cultivation and marketing.

Studies have also provided evidences that $L$. sulphureus contains several bioactive components with outstanding properties to treat different types of disorders. Among the important noteworthy aspects are free radical scavenging, antibacterial, anticancer and anti-diabetic activities. However, most of the research has been published based on in vitro studies and very few in vivo experimentation has been performed. Thus in future research, clinical studies are essential to confirm the safety and effects of these fungus derived compounds. Furthermore, attention should be given to pure components in order to get more information about their biological activities. Detailed studies should be carried out on the mechanism of action as data in this regard is not satisfactory.

Nevertheless, the key message of the overview is that being a source of diverse components in addition with nutritive value there is no direct application of the mushroom. Thus a collaborative research work among biologists, chemists, food experts and pharmaceutics is highly needed to enhance the societal use of L. sulphureus as food and medicine.

\section{CONFLICT OF INTEREST}

The authors report no conflicts of interest.

\section{ABBREVIATIONS USED}

RDA: Recommended daily allowances; DW: Dry weight; HPLC: High performance liquid chromatography; PUFA: Polyunsaturated fatty acids; DPPH: 2,2-Diphenyl-1-picrylhydrazyl; TBARS: Thiobarbituric acid reactive substances; FRAP: Ferric-reducing antioxidant power; ABTS: 2,2'-Azinobis(3-Ethylbenzthiazoline-6-Sulfonate); MFC: Minimum fungicidal concentration; MIC: Minimum inhibitory concentration; MTT: 3-(4,5-dimethylthiazol-2-yl)-2,5-diphenyltetrazolium bromide; iNOS: Inducible nitric oxide synthase; TNF- $\alpha$ : Tumour necrosis factor- $\alpha$; COX-2: Cyclooxygenase-2; STZ: Streptozotocin; AST: Aspartate aminotransferase; ALT: Alanine aminotransferase; $\mathbf{C C l}_{4}$ : Carbon tetrachloride.

\section{REFERENCES}

1. Radic N, Injac R, Strukelj B. Sulphur tuft culinary-medicinal mushroom, Laetiporus sulphureus (Bull.: Fr.) Murrill (Aphyllophoromycetideae): bioactive compounds and pharmaceutical effects (review). Int J Med Mushrooms. 2009; $11(2): 103-6$.

2. Luangharn T, Hyde KD, Chukeatirote E. Proximate analysis and mineral content of Laetiporus sulphureus strain MFLUCC 12-0546 from Northern Thailand. Chiang Mai J Sci. 2014;41(4):765-70.

3. Kovács D, Vetter J. Chemical composition of the mushroom Laetiporus sulphureus (Bull.) Murill. Acta Aliment. 2015;44(1):104-10.

4. Petrovic J, Stojkovic, D, Reis FS, Barros L, Glamoclija J, Ciric A et al. Study on chemical, bioactive and food preserving properties of Laetiporus sulphureus (Bull.: Fr.) Murr. Food Funct. 2014;5(7):144-51.

5. Klaus A, Kozarski M, Niksic M, Jakovljevic D, Todorovic N, Stefanoska I et al. The edible mushroom Laetiporus sulphureus as potential source of natural antioxidants. Int J Food Sci Nutr. 2012;64(5):599-610.

6. Alquini G, Carbonero ER, Rosado FR, Cosentino C, lacomini M. Polysaccharides from the fruit bodies of the basidiomycete Laetiporus sulphureus (Bull.: Fr.) Murr. FEMS Microbiol Lett. 2004;230(1):47-52.

7. Gardezi SRA. New and unreported species of mushrooms of Azad Jammu and Kashmir, Pakistan. Arch Phytopathology Plant Protect. 2005;38(1):41-51.

8. Smith AH, Weber NS. The Mushroom Hunter's Field Guide. University of Michigan Press, 1980.

9. Wiater A, Pleszczynska M, Szczodrak J, Janusz G. Comparative studies on the induction of Trichoderma harzianum Mutanase by $\alpha$-(1 $\rightarrow 3)$-glucan-rich fruiting bodies and mycelia of Laetiporus sulphureus. Int J Mol Sci. 2012;13:9584-98.

10. Rapior S, Konska G, Guillot J, Andary C, Bessiere JM. Volatile composition of Laetiporus sulphureus. Crytogamie Mycol. 2000;21(1):67-72.
11. Grienke U, Zöll M, Peintner U, Rollinger JM. European medicinal polypores-A modern view on traditional uses. J Ethnopharmacol. 2014;154:564-83.

12. Zjawiony JK. Biologically active compounds from Aphyllophorales (polypore) fungi. J Nat Prod. 2004;67(2):300-10.

13. Olennikov DN, Tankhaeva IM, Agafonova SV. Antioxidant components of Laetiporus sulphureus (Bull.: Fr.) Murr. fruit bodies. Appl Biochem Microbiol. 2011;47(4):419-25.

14. Valverde ME, Hernandez-Perez T, Paredes-Lopez O. Edible mushrooms: improving human health and promoting quality life. Int J Microbiol. 2015;Article ID 376387:14 pages.

15. Chan P, Kanagasabapathy G, Tan Y, Sabaratnam V, Kuppusamy UR. Amauroderma rugosum (Blume and T. Nees) Torrend: Nutritional composition and antioxidant and potential anti-inflammatory properties. Evid Based Complement Alternat Med. 2013;Article ID 304713:10 pages.

16. Bernas E, Jaworska G, Lisiewska Z. Edible mushrooms as a source of valuable nutritive constituents. Acta Sci Pol Technol Aliment. 2006;5(1):5-20.

17. Aishah MS, Rosli WI. Effect of different drying techniques on the nutritional values of oyster mushroom (Pleurotus sajor-caju). Sains Malays. 2013;42(7): 937-94.

18. Wani BA, Bodha $\mathrm{RH}$, Wani $\mathrm{AH}$. Nutritional and medicinal importance of mushrooms. J Med Plants Res. 2010;4(24):2598-604.

19. Ayaz FA, Torun H, Özel A, Col M, Duran C, Sesli E et al. Nutritional value of some wild edible mushrooms from Black Sea Region (Turkey). Turk J Biochem. 2011;36(3):213-21.

20. Friedman M. Nutritional value of proteins from different food sources. A review J Agric Food Chem. 1996;44(1):6-29.

21. Agafonova SV, Olennikov DN, Borovskii GB, Penzina TA. Chemical composition of fruiting bodies from two strains of Laetiporus sulphureus. Chem Nat Compd. 2007;43(6):687-8.

22. Palazzolo E, Gargano ML, Venturella G. The nutritional composition of selected wild edible mushrooms from Sicily (southern Italy). Int J Food Sci Nutr. 2012:63(1):79-83.

23. Ericsson DCB, Ivonne JNR. Sterol composition of the macromycete fungus Laetiporus sulphureus. Chem Nat Compd. 2009;45(2):193-6.

24. Kanzler S, Manschein M, Lammer G, Wagner K. The nutrient composition of European ready meals: Protein, fat, total carbohydrates and energy. Food Chem. 2015;172:190-6.

25. Kalac P. A review of chemical composition and nutritional value of wild-growing and cultivated mushrooms. J Sci Food Agric. 2013;93(2):209-18.

26. Cheung, PCK. Mini-review on edible mushrooms as source of dietary fiber: Preparation and health benefits. Food Sci Human Wellness. 2013;2:162-6.

27. Marshall MR. Ash Analysis Food Analysis. Springer, New York, 2010.

28. Saha D, Sundriyal M, Sundriyal RC. Diversity of food composition and nutritive analysis of edible wild plants in a multi-ethnic tribal land, Northeast India; an important facet for food supply. Indian J Tradit Knowl. 2014;13(4):698-705.

29. Soetan KO, Olaiya CO, Oyewole OE. The importance of mineral elements for humans, domestic animals and plants: A review. Afr J Food Sci. 2010;4(5):200-22

30. Khan SH, lqbal J. Recent advances in the role of organic acids in poultry nutrition. J Appl Anim Res. 2016;44(1):359-69.

31. Olennikov DN, Agafonova SV, Nazarova AV, Borovskii GB, Penzina TA. Organic acids and carbohydrates from Laetiporus sulphureus fruiting bodies. Chem Nat Compd. 2008;44(6):762-3.

32. Olennikov DN, Agafonova SV, Borovskii GB, Penzina TA, Rokhin AV. Alkali-soluble polysaccharides of Laetiporus sulphureus (Bull.: Fr.) Murr fruit bodies. Appl Biochem Microbiol. 2009;45(6):626-30.

33. Fan Q, Yin X, Li Z, Li Y, Liu J, Feng T et al. Mycophenolic acid derivatives from cultures of the mushroom Laetiporus sulphureus. Chin J Nat Med. 2014;12(9):685-8.

34. Krzyczkowski W, Malinowska E, Suchocki P, Kleps J, Olejnik M, Herold F Isolation and quantitative determination of ergosterol peroxide in various edible mushroom species. Food Chem. 2009;113(1):351-5

35. Shiono Y, Tamesada Y, Muravayev YD, Murayama T, Ikeda M. N-Phenethylhexadecanamide from the edible mushroom Laetiporus sulphureus. Nat Prod Res. 2005;19(4):363-6

36. Heleno SA, Barros L, Martins A, Queiroz MJRP, Santos-Buelga C, Ferreira ICFR Phenolic, polysaccaridic, and lipidic fractions of mushrooms from Northeastern Portugal: Chemical compounds with antioxidant properties. J Agric Food Chem. 2012;60(18):4634-40.

37. Varrot A, Basheer SM, Imberty A. Fungal lectins: structure, function and potential applications. Curr Opin Struct Biol. 2013;23(5):678-85.

38. Villares A, Mateo-Vivaracho L, Guillamon E. Structural features and healthy properties of polysaccharides occurring in mushrooms. Agriculture. 2012;2(4):452-71.

39. Acharya K, Ghosh S, Khatua S, Mitra P. Pharmacognostic standardization and antioxidant capacity of an edible mushroom Laetiporus sulphureus. J Verbrauch Lebensm. 2016;11(1):33-42.

40. Turkoglu A, Duru ME, Mercan N, Kivrak I, Gezer K. Antioxidant and antimicrobial activities of Laetiporus sulphureus (Bull.) Murrill. Food Chem. 2007;101(1):267-73. 
41. Sulkowska-Ziaja K, Musznska B, Motyl P, Pasko P, Ekiert H. Phenolic compounds and antioxidant activity in some species of Polyporoid mushrooms from Poland. Int J Med Mushrooms. 2012;14(4):385-93.

42. Kim S, Lee I, Jung Y, Yeom J, Ki D, Lee M et al. Mushrooms collected from Deogyu Mountain, Muju, Korea and their antioxidant activity. Mycobiol. 2012;40(2):134-7.

43. Prasad R, Varshney VK, Harsh NS, Kumar M. Antioxidant capacity and tota phenolics content of the fruiting bodies and submerged cultured mycelia of sixteen higher basidiomycetes mushrooms from India. Int J Med Mushrooms. 2015;17(10):933-41.

44. Lindequist $U$, Niedermeyer THJ, Jülich $W$. The pharmacological potential of mushrooms. eCAM. 2015;2(3):285-99.

45. Šiljegovic JD, Stojkovic DS, Nikolic MM, Glamoclija JM, Sokovic MD, Ciric M. Antimicrobial activity of aqueous extract of Laetiporus sulphureus (Bull.: Fr.) Murill. Zbornik Matice Srpske za Prirodne Nauke. 2011;(120):297-303.

46. Petrovic J, Glamoclija J, Stojkovic DS, Ciric A, Nikolic M, Bukvicki D et al. Laetiporus sulphureus, edible mushroom from Serbia: Investigation on volatile compounds, in vitro antimicrobial activity and in situ control of Aspergillus flavus in tomato paste. Food Chem Toxicol. 2013;59:297-302.

47. Sinanoglou VJ, Zoumpoulakis P, Heropoulos G, Proestos C, Ciric A, Petrovic J et al. Lipid and fatty acid profile of the edible fungus Laetiporus sulphureus. Antifungal and antibacterial properties. J Food SciTechnol. 2015;52(6):3264-72.

48. Mlinaric A, Kac J, Pohleven F. Screening of selected wood-damaging fungi for the HIV-1 reverse transcriptase inhibitors. Acta Pharm. 2005;55(1):69-79.

49. Cui L, Mharakurwa S, Ndiaye D, Rathod PK, Rosenthal PJ. Antimalarial drug resistance: literature review and activities and findings of the ICEMR network. Am J Trop Med Hyg. 2015;93(3):57-68.

50. Lovy A, Knowles B, Labbe R, Nolan L. Activity of edible mushrooms against the growth of human T4 leukemic cancer cells, HeLa cervical cancer cells, and Plasmodium falciparum. J Herbs Spices Med Plants. 1999;6(4):49-57.

51. Patel S, Goyal A. Recent developments in mushrooms as anti-cancer therapeutics: a review. 3 Biotech. 2012;2(1):1-15.

52. Song $F$, Liu $Y$, Kong $X$, Chang $W$, Song $G$. Progress on understanding the anticancer mechanisms of medicinal mushroom: Inonotus Obliquus. Asian Pac J Cancer Prev. 2013;14(3):1571-8.

53. Yin X, Li Z, Li Y, Feng T, Liu J. Four lanostane-type triterpenes from the fruiting bodies of mushroom Laetiporus sulphureus var. miniatus. J Asian Nat Prod Res. 2015;17(8):793-9.

54. Yoshikawa K, Bando S, Arihara S, Matsumura E, Katayama S. A benzofuran glycoside and an acetylenic acid from the fungus Laetiporus sulphureus var. miniatus. Chem Pharm Bull. 2001;49(3):327-9.

55. He J, Tao J, Miao X, Feng Y, Bu W, Dong Z et al. Two new illudin type sesquiter penoids from cultures of Phellinus tuberculosus and Laetiporus sulphurous. J Asian Nat Prod Res. 2015;17(11):1054-8.

56. Wiater A, Paduch R, Pleszczynska M, Próchniak K, Choma A, KandeferSzerszen $\mathrm{M}$ et al. $\alpha-(1 \rightarrow 3)-$-Glucans from fruiting bodies of selected macromycetes fungi and the biological activity of their carboxymethylated products. Biotechnol Lett. 2011;33:787-95.
57. Lear MJ, Simon O, FoleyTL, Burkart MD, Baiga TJ, Noel JP et al. Laetirobin from the Parasitic Growth of Laetiporus sulphureus on Robinia pseudoacacia. J Nat Prod. 2009;72(11):1980-7.

58. León F, Quintana J, Rivera A, Estévez F, Bermejo J. Lanostanoid triterpenes from Laetiporus sulphureus and apoptosis induction on $\mathrm{HL}-60$ human myeloid leukemia cells. J Nat Prod. 2004;67(12):2008-11.

59. Zhang J, Wen G, Zhang L, Duan D, Ren Z. Sulphureuine B, a drimane type sesquiterpenoid isolated from Laetiporus sulphureus induces apoptosis in glioma cells. Bangladesh J Pharmacol. 2015;10(4):844-53.

60. BiW-P, Man H-B, Man M-O. Efficacy and safety of herbal medicines in treating gastric ulcer: A review. World J Gastroenterol. 2014;20(45):17020-8.

61. Wang J, Sun W, Luo H, He H, Deng W, Zou K et al. Protective effect of Eburicoic Acid of the chicken of the woods mushroom, Laetiporus sulphureus (higher basidiomycetes), against gastric ulcers in mice. Int J Med Mushrooms. 2015;17(7):619-26.

62. Soares AA, Sá-Nakanishi AB, Bracht A, Costa SMG, Koehnlein EA, Souza CGM et al. Hepatoprotective effects of mushrooms. Molecules. 2013;18(7):7609-30.

63. Chatterjee A, Acharya K. Include mushroom in daily diet-A strategy for better hepatic health. Food Rev Int. 2016;32(1):68-97.

64. Sun W, He H, Wang J, Wu L, Cheng F, Deng Z. The main components analysis of Laetiporus sulphureu crude extract and its hepatoprotective effect on carbon tetrachloride-induced hepatic fibrosis in rats. Appl Mechanics Materials. 2014; 568-570:1934-9.

65. Elsayed EA, Enshasy HE, Wadaan MAM, Aziz R. Mushrooms: a potential natural source of anti-inflammatory compounds for medical applications. Mediators Inflamm. 2014; Article ID 805841:15 pages.

66. Saba E, Son Y, Jeon BR, Kim S, Lee I, Yun B et al. Acetyl eburicoic acid from Laetiporus sulphureus var. miniatus suppresses inflammation in murine macrophage Raw 264.7 Cells. Mycobiology. 2015;43(2):131-6.

67. Singdevsachana SK, Auroshreeb P, Mishrab J, Baliyarsinghb B, Tayunga K, Thatoi $\mathrm{H}$. Mushroom polysaccharides as potential prebiotics with their antitumor and immunomodulating properties: A review. Bioactive Carbohydr Dietary Fibre. 2016;7(1):1-14

68. Jeong SM, Kang BW, Park JU, Kim MJ, Lee HH, Choi YH et al. Biochemical characterization of the exopolysaccharide purified from Laetiporus sulphureus mycelia. J Microbiol Biotechnol. 2011;21(12):1287-93.

69. Lo H, Wasser SP. Medicinal mushrooms for glycemic control in diabetes mellitus: history, current status, future perspectives, and unsolved problems (review). Int J Med Mushrooms. 2011;13(5):401-26.

70. Hwang HS, Yun JW. Hypoglycemic effect of polysaccharides produced by submerged mycelial culture of Laetiporus sulphureus on streptozotocin-induced diabetic rats. Biotechnol. Bioprocess Eng. 2010;15(1):173-81.

71. Okamura T, Takeno T, Dohi M, Yasumasa I, Hayashi T, Toyoda M et al. Development of mushrooms for thrombosis prevention by protoplast fusion. J Biosci Bioeng. 2000;89(5):474s-8.
GRAPHICAL ABSTRACT

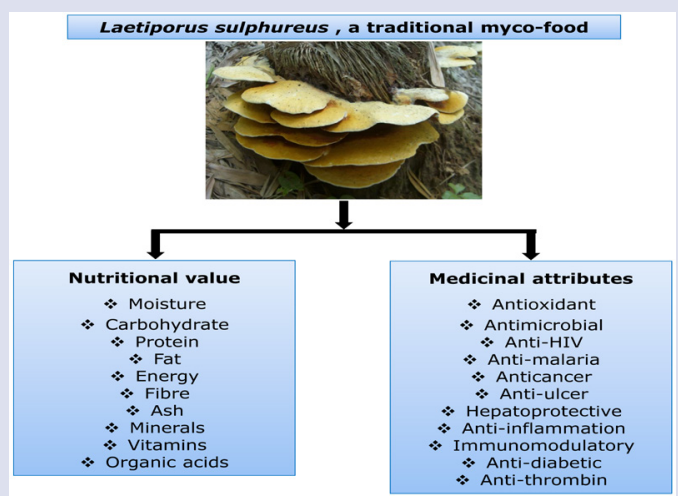

\section{SUMMARY}

- Since antiquity, mushrooms have been prized by humankind particularly for its taste, aroma and therapeutic value. Laetiporus sulphureus is one of such macrofungus that has long been valued by native tribal community. This sulphur yellow coloured wild polyporus taxon is abundantly found all over the globe and popularly known as "chicken of the woods" due to its texture. Ethnically, the mushroom has become a popular choice in regular cuisine as well as home remedy to treat a number of diseases. Such enormous cultural significance instantly captured attention of researchers during advent of science; as a result the species gradually emerged as a reservoir of nourishment and bioactive components. So far, a large number of papers have been published on L. sulphureus from different nations demanding congregation of their opinion, outputs and findings. In that note, the present review was aimed to assemble overall information on $L$. sulphureus with special emphasis on nutritional and medicinal importance. The attempt would be regarded successful if it can augment scientific concern on this magical mushroom to serve humankind. 


\section{ABOUT AUTHORS}

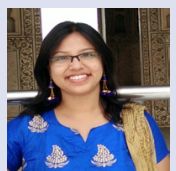

Miss Somanjana Khatua: M.Sc, Research Scholar, Molecular and Applied Mycology and Plant Pathology Laboratory, Department of Botany, University of Calcutta.

Miss Sandipta Ghosh: M.Sc, Research Scholar, Molecular and Applied Mycology and Plant Pathology Laboratory, Department of Botany, University of Calcutta.

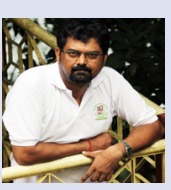

Prof. Krishnendu Acharya: M.Sc., M.Tech, Ph.D, Professor, Molecular and Applied Mycology and Plant Pathology Laboratory, Department of Botany, University of Calcutta.

Cite this article: Khatua S, Ghosh S, Acharya K. Laetiporus sulphureus (Bull.: Fr.) Murr. as Food as Medicine. Pharmacog J. 2017;9(6s):s1-s15. 